RESEARCH ARTICLE

\title{
Influence of soil properties on archaeal diversity and distribution in the McMurdo Dry Valleys, Antarctica
}

\author{
Ingrid Richter ${ }^{1}$, Craig W. Herbold ${ }^{1,2}$, Charles K. Lee ${ }^{1,2}$, Ian R. McDonald ${ }^{1,2}$, John E. Barrett ${ }^{3}$ \& \\ Stephen C. Cary ${ }^{1,2,4}$
}

\begin{abstract}
${ }^{1}$ School of Science, University of Waikato, Hamilton, New Zealand; ${ }^{2}$ International Centre for Terrestrial Antarctic Research, University of Waikato, Hamilton, New Zealand; ${ }^{3}$ Department of Biological Sciences, Virginia Tech, Blacksburg, VA, USA; and ${ }^{4}$ College of Marine and Earth Studies, University of Delaware, Lewes, DE, USA
\end{abstract}

\author{
Correspondence: Stephen C. Cary, School \\ of Science, University of Waikato, Private Bag \\ 3105, Hamilton, New Zealand. \\ Tel.: +64 7 838-4593; \\ fax: +64 7838 4324; \\ e-mail: caryc@waikato.ac.nz
}

Received 10 December 2013; revised 27 February 2014; accepted 5 March 2014

DOI: $10.1111 / 1574-6941.12322$

Editor: John Priscu

\section{Keywords}

Antarctic soils; Archaea; Euryarchaeota; Thaumarchaeota; pyrosequencing.

\begin{abstract}
Archaea are the least understood members of the microbial community in Antarctic mineral soils. Although their occurrence in Antarctic coastal soils has been previously documented, little is known about their distribution in soils across the McMurdo Dry Valleys, Victoria Land. In this study, terminal-restriction fragment length polymorphism (t-RFLP) analysis and 454 pyrosequencing were coupled with a detailed analysis of soil physicochemical properties to characterize archaeal diversity and identify environmental factors that might shape and maintain archaeal communities in soils of the three southern most McMurdo Dry Valleys (Garwood, Marshall, and Miers Valley). Archaea were successfully detected in all inland and coastal mineral soils tested, revealing a low overall richness (mean of six operational taxonomic units [OTUs] per sample site). However, OTU richness was higher in some soils and this higher richness was positively correlated with soil water content, indicating water as a main driver of archaeal community richness. In total, 18 archaeal OTUs were detected, predominately Thaumarchaeota affiliated with Marine Group 1.1b (> $80 \%$ of all archaeal sequences recovered). Less abundant OTUs ( $2 \%$ of all archaeal sequences) were loosely related to members of the phylum Euryarchaeota. This is the first comprehensive study showing a widespread presence and distribution of Archaea in inland Antarctic soils.
\end{abstract}

\section{Introduction}

The McMurdo Dry Valleys of Antarctica encompass the largest ice-free area $\left(4500 \mathrm{~km}^{2}\right)$ on the Antarctic continent (Levy, 2012). These typically U-shaped glacial valleys were primarily formed by a series of major glacial advances of ice sheets located between the Polar Plateau and the western coast of the Ross Sea, Southern Victoria Land (Denton et al., 2004). Each of these westward flowing ice fluctuations was successively less extensive than the former (Brook et al., 1995; Denton et al., 2004) resulting in different types of deposits and landforms within each valley, that is, different types of glacial push moraines, calcareous sandy eolian and fluvial sediments, and bedrock dominated by granite and metamorphosed rocks (Elberling et al., 2006). Classified as a hyperarid desert, Dry Valley soils are thought to be the driest, coldest ecosystem on Earth (Stonehouse, 2002). Due to the dry atmosphere, snowfall is typically ablated almost immediately, resulting in minimal liquid-water input to soils (Wynn-Williams, 1990; Doran et al., 2002; Gooseff et al., 2012; Eveland et al., 2013). Dry Valley soils are also characterized by large daily temperature variations during the Austral summer $\left(-12\right.$ to $5^{\circ} \mathrm{C}$ ) (Doran et al., 2002; Aislabie et al., 2006), high salinity (Bockheim, 1997; Poage et al., 2008), and low nutrient availability (Vishniac, 1993). The effects of such severe physiochemical soil conditions combine to create one of the harshest environments known to support life (Bockheim, 2002; Barrett et al., 2007). Consequently, vascular plants and vertebrates are absent, while a number of invertebrate species and bacteria are widely distributed and dominate the entire Dry Valley soil 
food web (Adams et al., 2006). Physicochemical soil parameters such as availability of water, soil organic carbon and nitrogen, salinity, and temperature are the determining factors of habitat suitability for soil communities (Freckman \& Virginia, 1997; Barrett et al., 2004; Gregorich et al., 2006).

Bacterial diversity is well documented within Dry Valley soil microbial communities (Wynn-Williams, 1990; Barrett et al., 2006; Smith et al., 2006; Niederberger et al., 2008; Pointing et al., 2009; Lee et al., 2012). Although surprisingly high levels of bacterial diversity have been reported (Smith et al., 2006; Cary et al., 2010; Lee et al., 2012), little is known about the presence, diversity, and community composition of Archaea within Dry Valley soils (Pointing et al., 2009; Yergeau et al., 2009). Only coastal soils, adjacent to the Ross Sea, have been reported to harbor archaeal communities (Ayton et al., 2010). This is in stark contrast to temperate soils, where molecular studies have revealed a widespread distribution of both Thaumarchaeota and Euryarchaeota (Bintrim et al., 1997; Jurgens et al., 1997; Buckley et al., 1998; Ochsenreiter et al., 2003; Nicol \& Schleper, 2006). Thaumarchaeota may account for up to $5 \%$ of the total temperate soil prokaryotic community (Buckley et al., 1998; Ochsenreiter et al., 2003) but are highly restricted to a few lineages, namely Marine groups 1.1b and 1.1c (Jurgens et al., 1997; Ochsenreiter et al., 2003; Nicol et al., 2006). Although a worldwide distribution has been assumed due to their detection in diverse soil environments (Ochsenreiter et al., 2003; Nicol et al., 2005, 2006), molecular studies failed to detect Archaea in many Antarctic soils, including soils from the western Antarctic Peninsula (Yergeau et al., 2009) and from McKelvey Valley in the McMurdo Dry Valleys (Pointing et al., 2009).

It has been proposed that Dry Valley soil is an example of an environment where abiotic factors (e.g., moisture, $\mathrm{pH}$, conductivity) have a stronger influence on the diversity and structure of communities than biotic factors (e.g., competition, herbivory, predation) (Convey, 1996; Hogg et al., 2006; Pointing et al., 2009; Zeglin et al., 2011; Lee et al., 2012). This makes Dry Valley soils a perfect model system for investigating the direct effects of physicochemistry on microbial biodiversity and ecosystem function, which is one of the main questions being addressed by the New Zealand Terrestrial Antarctic Biocomplexity Survey (nzTABS, http://nztabs.ictar.aq). As part of nzTABS, this study aims to characterize the composition and structure of archaeal communities across a wide range of Antarctic soils and to identify environmental factors influencing their distribution within three smaller valleys (Miers, Garwood, and Marshall Valleys) in the southern part of the McMurdo Dry Valley system.

\section{Materials and methods}

\section{Site location, sampling, and physicochemical analysis}

Mineral soil samples were collected from four areas in the McMurdo Dry Valleys (Fig. 1), located between the Royal Society Range and the McMurdo Sounds at the lobe of the Koettlitz Glacier: Miers Valley $\left(78^{\circ} 6^{\prime} \mathrm{S} 164^{\circ} 0^{\prime} \mathrm{E}\right)$, Marshall Valley $\left(78^{\circ} 4^{\prime} \mathrm{S} 164^{\circ} 10^{\prime} \mathrm{E}\right)$, Garwood Valley $\left(78^{\circ} 2^{\prime} \mathrm{S}\right.$ $164^{\circ} 10^{\prime} \mathrm{E}$ ), and Shangri-La, an elevated plain west of Marshall Valley. Each valley is characterized by three different types of glacial push moraines: (i) Moraine 1, located on ridges up to $550 \mathrm{~m}$ high, is characterized by the relatively old 'McMurdo Glaciation' deposits such as red porphyritic rocks and wind-planed granite boulders (Pewe, 1958, 1960); (ii) Moraine 2, located inland on the valley floor and along the coastal foothills, is characterized by older glacial deposits ('Marshall Drift'); and (iii) Moraine 3, located around the coastal margins, is the result of the youngest glaciation ('Ross Sea Drift') and is composed of till and stratified sediments made up of clasts of dark, volcanic rocks derived from the McMurdo Volcanic Group (Brook et al., 1995; Denton et al., 2004). Samples were collected along four transects (Fig. 1). A single transect was laid across each valley floor running from the coast up to the inland glaciers at the end of each valley (three total). The fourth transect crossed the granite ridges of all three valleys (hereinafter 'ridge transect', Fig. 1). Additional alluvial soil samples were taken from the shores of Lake Miers (Miers Valley), Lake Colleen (Garwood Valley), Lake Buddha (Shangri-La) and a pond in the upper Marshall Valley.

A total of 36 samples (400 g each) were collected from the top $2 \mathrm{~cm}$ of soil in $42 \mathrm{oz}$ Whirlpak bags (Nasco, Fort Atkinson, WI) with a sterile spatula. Large stones and pebbles ( $>2 \mathrm{~cm}$ diameter) were removed; the samples homogenized and then split into two portions. One portion was used immediately for electrical conductivity, $\mathrm{pH}$, and ATP measurements, and the remainder stored at $-20{ }^{\circ} \mathrm{C}$ for later analyses.

Electrical conductivity and $\mathrm{pH}$ were measured in the field using a CyberScan PC 510 Bench Meter (Eutech Instruments Pte Ltd., Singapore) using the slurry technique (Edmeades et al., 1985). ATP content was determined in the field using the $3 \mathrm{M}^{\mathrm{TM}}$ Clean-Trace ${ }^{\mathrm{TM}}$ Beverage Test Kit (3M Centre, St. Paul, MN) following the manufacturer's recommendations. Moisture content of soils was measured gravimetrically in the laboratory by drying $40 \mathrm{~g}$ of each soil sample at $105{ }^{\circ} \mathrm{C}$ until samples reached a consistent weight (Barrett et al., 2004). To determine total soil organic carbon and nitrogen, each soil sample 
Fig. 1. Map of the Ross Sea Region, Antarctica showing the McMurdo Dry Valleys (black rectangle) and the study site (yellow rectangle). 2. Locations of sampling points in Miers Valley, Marshall Valley, Garwood Valley (red), and Shangri-La (yellow). Red lines denote moraine transects for each valley, and the green line shows the ridge transect across all three valleys.

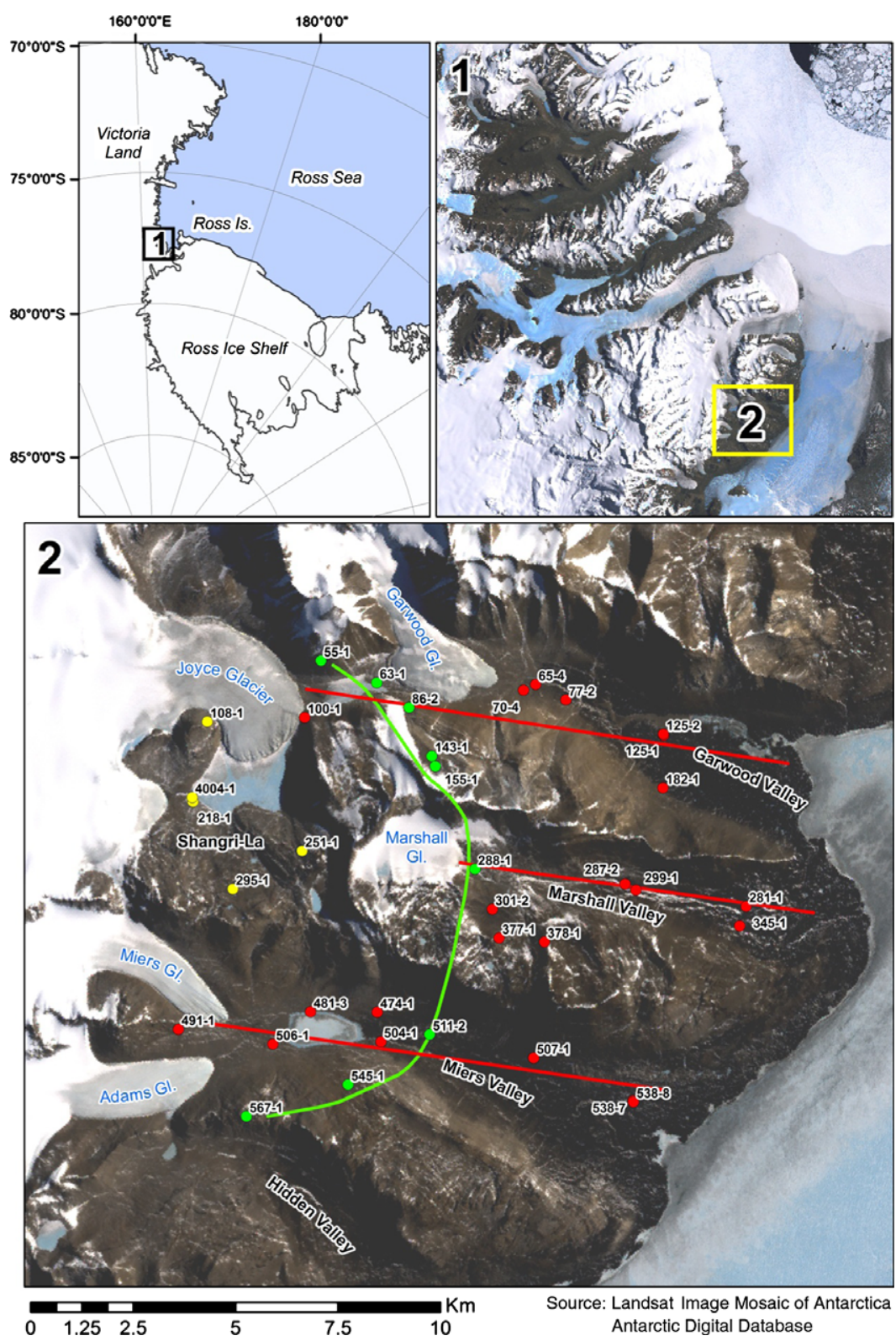

a potential problem. Archaea-specific PCR of the $16 \mathrm{~S}$ rRNA gene was performed in $25 \mu \mathrm{L}$ reactions containing $200 \mathrm{nM}$ of primer A92F (5'-FAM-ACGGCTCAGTAAC RC-3') (Buckley et al., 1998), $100 \mathrm{nM}$ of primer A836R (5'-GTGCTCCCCCGCCAATTCCT-3') (Stahl \& Amann, 1991), $3 \mathrm{mM} \mathrm{MgCl}$, $1 \times$ Platinum Taq PCR buffer, $0.4 \mathrm{U}$ of Platinum Taq DNA polymerase (Invitrogen Ltd., New Zealand), $32 \mu \mathrm{g} \mathrm{mL}^{-1}$ bovine serum albumin, $200 \mu \mathrm{M}$ of each dNTP (Roche Diagnostics, New Zealand), $10 \mathrm{ng}$ of extracted template DNA, and UltraPure ${ }^{\mathrm{TM}}$ distilled water (Invitrogen Ltd.). The master mix, containing all reagents except the fluorescently labeled forward primer, was treated with $0.1 \mu \mathrm{g} \mu \mathrm{L}^{-1}$ ethidium monoazide bromide (Biotium Inc., Hayward, CA) by incubation in the dark 
for $1 \mathrm{~min}$ followed by exposure to high wattage light for 1 min (Rueckert \& Morgan, 2007). Amplification was performed using an initial denaturation step at $94{ }^{\circ} \mathrm{C}$ for 2 min followed by 35 cycles of $94{ }^{\circ} \mathrm{C}, 20 \mathrm{~s} ; 56{ }^{\circ} \mathrm{C}, 10 \mathrm{~s}$; $72{ }^{\circ} \mathrm{C}, 40 \mathrm{~s}$; and a final extension step of $72{ }^{\circ} \mathrm{C}$ for $5 \mathrm{~min}$. Triplicate PCRs were pooled together to minimize stochastic PCR bias, purified (UltraClean ${ }^{\mathrm{TM}} 15$ DNA Purification Kit; MO BIO Laboratories Inc., Carlsbad, CA), resuspended in MilliQ water, and quantified using the Qubit $^{\circledR}$ fluorometer (Quant-iT ${ }^{\mathrm{TM}}$ dsDNA HS Assay Kit; Invitrogen Ltd.).

Purified amplicons (100 ng) were digested at $37{ }^{\circ} \mathrm{C}$ for $3 \mathrm{~h}$ in $20 \mu \mathrm{L}$ reactions containing $10-20 \mathrm{U}$ of MspI, $1 \times$ Buffer 4 (Thermo Fisher Scientific Inc.) and UltraPure ${ }^{\mathrm{TM}}$ distilled water followed by heat inactivation at $65{ }^{\circ} \mathrm{C}$ for $20 \mathrm{~min}$. All reactions were stored at $-20{ }^{\circ} \mathrm{C}$ until further analysis.

Aliquots $(2 \mu \mathrm{L})$ of the diluted ( 1 in 10 in UltraPure $\mathrm{CM}^{\mathrm{TM}}$ distilled water) restriction digest were denatured in the presence of $17.75 \mu \mathrm{L} \mathrm{Hi}-\mathrm{Di}^{\mathrm{TM}}$ Formamide at $95{ }^{\circ} \mathrm{C}$ for $4 \mathrm{~min}$ and then chilled to $4{ }^{\circ} \mathrm{C}$. The samples were loaded onto an ABI 3130 xI sequencer (PE Applied Biosystems, Foster City) and run under GeneScan mode at $15 \mathrm{kV}$ for $45 \mathrm{~min}$ according to the manufacturer's instruction. Each sample contained $0.25 \mu \mathrm{L}$ of the internal GS1200LIZ ZyStandard (PE Applied Biosystems) to determine the size of fluorescently labeled fragments during analysis.

\section{Data analysis}

T-RFLP electropherograms were processed using PEAKSCANNER $^{\text {TM }}$ v1.0 (PE Applied Biosystems). Peaks were denoised and binned using an in-house pipeline modified from Abdo et al. (2006) written using PYTHON 2.7.1 (Python Software Foundation) and R (http://www.r-project. org). Abdo's method was modified to model parameters for a log-normal distribution. Iteratively, peaks with an area exceeding the $99.9 \%$ cumulative distribution of the calculated log-normal distribution for noise were accepted as true peaks. Peaks were binned into t-RFs with width $=1 \mathrm{nt}$, and total peak area of each bin was used to calculate relative abundance of each $\mathrm{t}-\mathrm{RF}$ in a given dataset.

The influence of physicochemical variables on the community structure of the soil samples was assessed using BEST (Bio-Environment Stepwise) analysis with the PRIMER 6 software package (PRIMER-E Ltd., UK). The BEST procedure calculates the value of Spearman's rank correlation coefficient $(\rho)$ using every possible combination of variables until it finds the 'best' fit (i.e., the combination of parameters whose Euclidean distance matrix gives the highest $\rho$ ). The combination of geochemical variables yielding the highest $\rho$ are the most correlated with archaeal richness. Physicochemical variables (water, $\mathrm{pH}$, conductivity, and ATP) showing no linear relationship or a heavily skewed distribution were normalized using square root transformation prior to BEST analysis. Alpha-diversity (species richness) was analyzed using multiple regression, Pearson's product-moment correlation, and Spearman's rank correlation implemented in R.

\section{Pyrosequencing and noise removal}

Ten PCRs were run for each of the four samples (299-1, 377-1, 77-2, and 567-1, Table 1) following the t-RFLP amplification protocol described earlier. Individual PCRs were subsequently pooled together and gel-purified using the UltraClean ${ }^{\mathrm{TM}} 15$ DNA Purification Kit. Cleaned amplicons were used as template (125 ng) in a second PCR to attach 454-specific sequence tags to the 794-bp PCR product. Amplification was performed using 454specific archaeal primers Ar14A-A92F and ArB-A836R under conditions described for the t-RFLP PCR. Both primers contained an adapter sequence at the $5^{\prime}$ end, followed by a key sequence and a unique tag sequence (MID).

The final amplicon was gel-extracted using the UltraClean $^{\text {TM }} 15$ DNA Purification Kit, cleaned using the Agencourt AMPure XP Bead Cleanup Kit (Beckman Coulter Inc.) and quantified (Quant-iT ${ }^{\mathrm{TM}} \mathrm{dsDNA} H S$ Assay Kit). Sequencing was performed at the University of Waikato DNA Sequencing Facility (http://sci.waikato.ac.nz/research/ facilities/dna) using the GS Junior Titanium emPCR Kit (Lib-L), the GS Junior Titanium Sequencing Kit, PicoTiterPlate Kit, and GS Junior System sequencer (Roche 454 Life Sciences, Branford, CT) yielding a mean read length of $324 \mathrm{bp}$.

AMPLICONNOISE v1.22 (Quince et al., 2011) was used to process raw flowgrams from each sample separately. Reads matching sample-specific barcodes exactly were required to extend for at least 360 cycles before the first noisy signal (i.e., $0.5-0.7$ or no signal in all four nucleotides). Flowgrams were truncated at 360 cycles and processed using PYRONOISE and SEQNOISE (Quince et al., 2011). PCR chimeras were removed using PERSEUs, which is included within the AMPLICONNOISE package. Sequence predictions were first required to perfectly match primer sequences and then both barcode and primer sequences were removed.

\section{Identification of archaeal phylotypes}

To separate archaeal from bacterial sequences, taxonomy was assigned to each sequence using RDP Classifier (Wang et al., 2007). All sequences that were classified as either bacterial or archaeal at a high confidence level 
Table 1. Properties of soil samples analyzed and the number of t-RFLP phylotypes identified

\begin{tabular}{|c|c|c|c|c|c|c|c|c|c|c|c|c|}
\hline Samples & $\mathrm{GM}^{*}$ & Aspect & Height $^{\dagger}$ & Slope & $\mathrm{MC}^{\ddagger}$ & $\mathrm{pH}$ & $\mathrm{EC}^{\S}$ & ATPף & Total Organic C (\%) & Total N (\%) & C/N Ratio & t-RFLP Phylotypes** \\
\hline \multicolumn{13}{|c|}{ Miers Valley transect } \\
\hline $538-8$ & M3 & South & 100 & 5 & 0.75 & 8.6 & 670 & 13319 & 0.0239 & 0.0028 & 8.4 & 3 \\
\hline $538-7$ & M3 & South & 98 & 6 & 0.75 & 8.6 & 670 & 13319 & 0.3466 & 0.0522 & 6.6 & 5 \\
\hline $507-1$ & M3 & South & 216 & 17 & 0.52 & 8.3 & 5130 & 36519 & 0.0436 & 0.0068 & 6.4 & $13(2)$ \\
\hline $504-1$ & M2 & Flat & 161 & 6 & 1 & 9.2 & 130 & 16872 & 0.0391 & 0.0048 & 8.1 & $13(3)$ \\
\hline $506-1$ & M1 & North & 178 & 5 & 0.82 & 9.7 & 924 & 7457 & 0.0526 & 0.0055 & 9.4 & $8(2)$ \\
\hline $491-1$ & M1 & South & 393 & 16 & 0.99 & 9.2 & 140 & 30964 & 0.0825 & 0.0102 & 8.0 & $7(1)$ \\
\hline $474-1$ & Scr & South & 233 & 15 & 0.7 & 9.4 & 42 & 22617 & 0.0479 & 0.0047 & 10.0 & 10 \\
\hline $481-3$ & All & Flat & 164 & 5 & 1 & 9.8 & 370 & 99864 & 0.2566 & 0.0223 & 11.5 & $9(2)$ \\
\hline Mean & & & & & 0.82 & 9.1 & 1009 & 30116 & 0.1116 & 0.0136 & 8.5 & 8.5 \\
\hline Std & & & & & 0.16 & 0.5 & 1584 & 27874 & 0.1130 & 0.0156 & 1.6 & \\
\hline \multicolumn{13}{|c|}{ Marshall Valley transect } \\
\hline 281-1 & M3 & South & 172 & 9 & 0.59 & 7.5 & 789 & 53 & 0.0751 & 0.0072 & 10.4 & 3 \\
\hline $287-2$ & M2 & South & 237 & 12 & 0.99 & 9.8 & 336 & 21674 & 0.0455 & 0.0062 & 7.3 & 3 \\
\hline $345-1$ & M2 & North & 185 & 8 & 1.01 & 8.4 & 130 & 41447 & 0.5322 & 0.0768 & 6.9 & $8(1)$ \\
\hline $299-1^{\dagger \dagger}$ & M1 & North & 285 & 9 & 1.01 & 8.9 & 310 & 75331 & 0.1278 & 0.0161 & 7.9 & $7(2)$ \\
\hline $377-1^{\dagger \dagger}$ & Gra & East & 756 & 23 & 1 & 9.3 & 70 & 38739 & 0.0338 & 0.0031 & 10.7 & 9 \\
\hline $378-1$ & Sch & West & 782 & 15 & 1 & 9.2 & 90 & 28453 & 0.0474 & 0.0050 & 9.3 & 6 \\
\hline $301-2$ & All & Flat & 555 & Flat & 1 & 8.3 & 60 & 32991 & 0.0346 & 0.0035 & 9.8 & 11 \\
\hline Mean & & & & & 0.94 & 8.7 & 255 & 34098 & 0.1280 & 0.0168 & 8.9 & 6.7 \\
\hline Std & & & & & 0.1 & 0.7 & 242 & 21119 & 0.1678 & 0.0248 & 1.4 & \\
\hline \multicolumn{13}{|c|}{ Garwood Valley transect } \\
\hline $182-1$ & M3 & North & 104 & 10 & 0.99 & 8.6 & 136 & 10817 & 0.0316 & 0.0021 & 15.0 & $10(1)$ \\
\hline $125-2$ & M3 & North & 26 & 7 & 0.98 & 7.8 & 66 & 5980 & 0.1297 & 0.0138 & 9.3 & 3 \\
\hline $125-1$ & M3 & North & 30 & 8 & 0.9 & 8.2 & 46 & 17240 & 0.0283 & 0.0028 & 9.9 & $7(1)$ \\
\hline $100-1$ & M3 & East & 8 & 6 & 0.99 & 7.9 & 868 & 10270 & 0.0486 & 0.0049 & 9.9 & 8 \\
\hline $77-2^{\dagger \dagger}$ & M2 & North & 98 & 5 & 1 & 8.9 & 57 & 6665 & 0.0744 & 0.0093 & 7.9 & $10(1)$ \\
\hline $70-4$ & M2 & North & 134 & 4 & 0.99 & 9 & 114 & 11123 & 0.0502 & 0.0048 & 10.2 & 2 \\
\hline $65-4$ & M1 & North & 114 & 4 & 0.99 & 9.5 & 90 & 10725 & 0.0724 & 0.0025 & 27.9 & 3 \\
\hline Mean & & & & & 0.97 & 8.5 & 196 & 10402 & 0.0621 & 0.0057 & 12.9 & 4 \\
\hline Std & & & & & 0 & 0.6 & 276 & 3404 & 0.0321 & 0.0040 & 6.5 & \\
\hline \multicolumn{13}{|c|}{ Ridge transect } \\
\hline $567-1^{\dagger \dagger}$ & Gra & East & 647 & 16 & 1 & 7.8 & 90 & 7735 & 0.0446 & 0.0068 & 6.5 & 10 \\
\hline $545-1$ & Gne & North & 374 & 12 & 0.45 & 8.4 & 29 & 40034 & 0.0986 & 0.0139 & 7.0 & 1 \\
\hline $511-2$ & $\mathrm{M} 2$ & South & 203 & 6 & 0.51 & 9.7 & 73 & 5057 & 0.0209 & 0.0031 & 6.6 & 4 \\
\hline $288-1$ & M1 & East & 540 & 7 & 1.01 & 9.7 & 110 & 38069 & 0.0336 & 0.0031 & 10.6 & $15(2)$ \\
\hline $155-1$ & Gra & North & 910 & 22 & 0.99 & 8.3 & 33 & 2466 & $\mathrm{~N} / \mathrm{D}$ & $\mathrm{N} / \mathrm{D}$ & $\mathrm{N} / \mathrm{D}$ & $9(1)$ \\
\hline $143-1$ & Gra & North & 866 & 21 & 0.97 & 8.3 & 29 & 1155 & 0.0477 & 0.0050 & 9.5 & 5 \\
\hline $86-2$ & Gra & North & 462 & 26 & 0.99 & 9 & 48 & 3870 & 0.1142 & 0.0095 & 11.9 & 8 \\
\hline $63-1$ & All & Flat & 357 & 2 & 0.99 & 8.5 & 84 & 3739 & 0.0540 & 0.0053 & 10.1 & 2 \\
\hline $55-1$ & M1 & South & 678 & 36 & 0.99 & 9 & 56 & 20209 & 0.0378 & 0.0048 & 7.7 & 4 \\
\hline Mean & & & & & 0.87 & 8.7 & 61 & 13592 & 0.0564 & 0.0064 & 8.7 & 6.4 \\
\hline Std & & & & & 0.2 & 0.6 & 28 & 14603 & 0.0306 & 0.0034 & 1.9 & \\
\hline \multicolumn{13}{|c|}{ Shangri-La } \\
\hline 4004-1 & All & North & 393 & 3 & 0.41 & 9 & 58 & 861 & 0.1671 & 0.0041 & 39.9 & $2(1)$ \\
\hline $108-1$ & Gra & North & 564 & 30 & 0.98 & 8.6 & 61 & 45384 & 0.0747 & 0.0096 & 7.7 & $15(1)$ \\
\hline $251-1$ & Gra & North & 645 & 13 & 0.99 & 9.1 & 50 & 39488 & 0.0800 & 0.0095 & 8.3 & 9 \\
\hline 295-1 & Gra & East & 565 & 9 & 0.99 & 9 & 101 & 24164 & 0.0487 & 0.0061 & 7.9 & 1 \\
\hline $218-1$ & M1 & North & 400 & 6 & 0.98 & 8 & 754 & 10286 & 0.0425 & 0.0065 & 6.4 & 4 \\
\hline Mean & & & & & 0.87 & 8.7 & 205 & 24036 & 0.0826 & 0.0071 & 14 & 6.2 \\
\hline Std & & & & & 0.2 & 0.4 & 275 & 16856 & 0.0446 & 0.0021 & 12.9 & \\
\hline
\end{tabular}

*Geomorphology: M1, Moraine 1; M2, Moraine 2; M3, Moraine 3; Gra, Granite; Sch, Schist; Scr, Scree; All, Alluvia; Gne, Gneiss.

${ }^{\dagger}$ As meters above sea level.

\$Total soil moisture content as percentage.

\$Soil electrical conductivity in $\mu \mathrm{S} \mathrm{cm}^{-1}$.

${ }^{\top}$ As relative fluorescent units.

**Total number of phylotypes per sample based on t-RFLP results (unique phylotypes are given in parenthesis).

†These samples were used for 454 pyrosequencing. 
(> 80\%) were either removed (Bacteria) or retained (Archaea) for further analysis. Sequences that were classified as Archaea and Bacteria at a low confidence level $(<80 \%)$ were matched to genome sequences in GenBank (http://www.ncbi.nlm.nih.gov/) using BLAST at default settings. Sequences that were confidently identified as bacterial (>99\% max identity) were removed, and sequences that could feasibly have come from Archaea (> 70\% max identity) were retained. All archaeal sequences were then manually checked for chimeras by splitting the sequence in half, and using BLAST to find best hits within the NCBI genome database. If one half of the sequence could be confidently identified as bacterial (> 99\% max. identity) and the other half as archaeal, the sequence was regarded as chimeric and subsequently removed.

\section{Phylogenetic analysis}

Sequence alignment and all phylogenetic analyses were performed using MEGA 4 (Molecular Evolutionary Genetics Analysis software version 4.0, Tamura et al. 2007). Archaeal sequences and the bacterial isolate Thermoanaerobacter methranii (outgroup) were aligned using CLUSTALW (Thompson et al., 1994) and end-trimmed down to an overlapping region present in all sequences: the final length (in bases) of the overlapping region was $220 \mathrm{bp}$. All positions containing gaps and missing data were eliminated from the dataset (complete deletion option). There were a total of 177 positions in the final alignment. The unrooted phylogeny was inferred using the neighbor-joining algorithm (Saitou \& Nei, 1987) with Maximum Composite Likelihood Distances (Tamura et al., 2004) and tested using 1000 bootstraps. The resulting tree was rooted on T. methranii (outgroup) to define clades. Archaeal sequences generated in this study are deposited in the Sequence Read Archive (SRA) under accession numbers ERX141792-95 (experiments accessions) and ERR16591518 (runs accessions). Original pyrosequencing flowgram files are also available from the SRA database (http://www. ebi.ac.uk/ena/data/view/ERP001744).

\section{Richness estimation}

Pairwise distances between archaeal sequences were calculated using ESPRIT (Sun et al., 2009), and sequences were clustered into OTUs using mean neighbor clustering at a distance of 0.03 in мотнUR (Schloss et al., 2009). мотнUR was also used to generate Venn diagrams and rarefaction curves based on the number of observed OTUs and the Chaol richness estimator (Chao, 1987).

\section{Results}

\section{Soil characteristics}

Physicochemical properties of soil samples from four valleys studied are shown in Table 1. Cluster analysis based on Euclidean distance and multidimensional scaling (MDS) ordination revealed no significant differences in physicochemical properties between and within valleys (data not shown). All mineral soils were alkaline ranging from $\mathrm{pH} 7.5$ to 9.8. Mean soil moisture content was low in all samples, ranging from $0.82 \%$ (Miers Valley transect) to $0.97 \%$ (Garwood Valley transect). Electrical conductivity, a representation of salinity, was lowest in the ridge transect (ranging from 29 to $110 \mu \mathrm{S} \mathrm{cm}^{-1}$ ), while the highest value was recorded in Miers Valley transect $\left(5130 \mu \mathrm{Sm}^{-1}\right)$. ATP content, a proxy for biological activity, was low in Garwood Valley and ridge transects (5980-17 240 RFU and 1150-40 034 RFU, respectively), whereas samples from Miers Valley and Marshall Valley transects showed a high ATP content (7457-99 864 RFU and 21 764-75 $331 \mathrm{RFU}$, respectively) with one exception (53 RFU in Marshall Valley transect). Organic carbon and total nitrogen contents were very low in all samples (mean $0.09 \pm 0.01 \%$ and $0.03 \pm 0.005 \%$, respectively).

\section{Diversity and distribution of soil Archaea}

Archaeal signals were detected using t-RFLP analysis in all 36 soil samples, yielding a total of 21 unique t-RFLP phylotypes with a mean of six phylotypes in each sample (Table 1). The total number of phylotypes observed in each transect was estimated by pooling the phylotypes from all samples within each transect in silico. Species richness was highest in the Miers Valley transect (nine phylotypes per sample), followed by Marshall Valley (seven phylotypes), Garwood Valley (six phylotypes), and ridge transects (six phylotypes, Table 1).

The four samples selected for in-depth community analysis, using 454 pyrosequencing, were chosen based on (i) high t-RFLP species richness compared to the mean number of phylotypes per sample (> six phylotypes) and (ii) their geographical location within each valley, covering both the ridge transect (Miers Valley ridge and Miers Marshall Valley ridge) and different types of moraines (Marshall Valley moraine 1 and Garwood Valley moraine 2; Table 1). Sequencing yielded a total of 33707 reads, with a mean of 8427 reads per sample (Table 2). Flowgram clustering and denoising was performed, followed by the removal of low-quality sequencing tags, bacterial sequences, and chimeras (see Materials and methods), yielding a total of 20395 archaeal reads with a mean of 
Table 2. Summary of total sequences, total OTUs, and diversity estimates (calculated using mean neighbor at $3 \%$ distance) for four archaeal assemblages examined

\begin{tabular}{|c|c|c|c|c|c|c|c|c|c|}
\hline \multirow[b]{2}{*}{ Samples } & \multicolumn{5}{|c|}{ Number of tags } & \multicolumn{2}{|c|}{$\begin{array}{l}\text { Number of } \\
\text { OTUs }\end{array}$} & \multirow{2}{*}{$\begin{array}{l}\text { Chao1 } \\
\mathrm{H}\end{array}$} & \multirow{2}{*}{$\begin{array}{l}\text { Effort } \\
\text { I }\end{array}$} \\
\hline & A & B & C & D & E & $\mathrm{F}$ & G & & \\
\hline Garwood Valley moraine 2 & 7740 & $5217(25)$ & 80 & 4931 & 22 & 10 & 10 & 10.5 & 2564 \\
\hline Marshall Valley moraine 1 & 10349 & 7068 (14) & 181 & 6830 & 15 & 6 & 7 & 6 & 3226 \\
\hline Miers Marshall Valley ridge & 12423 & $8496(25)$ & 44 & 7012 & 5 & 5 & 9 & 11 & 1706 \\
\hline Miers Valley ridge & 3195 & $2108(8)$ & 64 & 1622 & 10 & 5 & 10 & 11 & 1543 \\
\hline Mean & 8427 & $5722(18)$ & 92 & 5099 & 12.75 & 6.5 & 9 & 9.6 & 2260 \\
\hline
\end{tabular}

A: Total number of tags matching MID without the preclustering step (see Materials and methods Pyrosequencing and noise removal). B: Total number of tags passing AmpLiconnolse (see Materials and methods Pyrosequencing and noise removal). Tags removed as Chimera in parenthesis. C: Number of unique tags passing AMpLCONNoISE. D: Number of archaeal tags after removal of Bacterial sequences and manually identified chimeras. E: Number of unique archaeal tags after removal of Bacterial sequences and manually identified chimeras. F: Number of OTUs based on 454 pyrosequencing clustered using mean neighbor at the $3 \%$ difference level. G: Number of OTUs based on t-RFLP results. H: Estimation of OTU richness in samples. I: Number of sequencing reads required for discovering a new OTU calculated using terminus of rarefaction curves in reads/OTU.

5099 tags per sample. The total number of unique reads was low (52, Table 2), and all unique reads were clustered into 18 distinct OTUs using average neighbor at 3\% distance.

Overall, the number of OTUs per sample was similar for both pyrosequencing (5-10 OTUs) and t-RFLP (7-10 OTUs, Table 2). Richness estimates (Chaol) based on the number of species observed using pyrosequencing agreed well with the number of OTUs detected using t-RFLP richness estimates (Table 2). The number of sequencing reads (effort) required to discover a new OTU was calculated by taking the inverse of the terminal slope of the rarefaction curves (Supporting information, Fig. S1) over the last 500 reads (Table 2). On average, 2895 reads would have been required to find a new OTU in moraine samples, whereas 1624 reads would have been required in ridge samples. These estimates suggest that the natural communities were very well sampled by the sequencing effort.

\section{Archaeal community composition and phylogenetic analysis}

Of the 18 unique archaeal OTUs obtained from 454 analysis, all but three were represented by sequences closely affiliated with members of the phylum Thaumarchaeota. The exceptions were OTUs 16-18, which belonged to the Euryarchaeota (Table S1). Thaumarchaeota were present in all soils, whereas Euryarchaeota (OTUs 16-18) were not detected in ridge samples (Table S1). Among known Thaumarchaea species, Nitrososphaera gargensis (accession number GU797786) was the closest relative of all observed thaumarchaeal sequences (87-98\% maximum identity). All thaumarchaeal sequences showed a high level of identity to existing environmental sequences in the database $(93-100 \%$ identity over the 780 nucleotides examined). Euryarchaeal sequences exhibited a similar pattern of similarity, showing a maximum identity of 80 $85 \%$ to isolates and $92-98 \%$ identity to environmental sequences.

\section{Thaumarchaeota}

Placement of OTUs within the Thaumarchaeota was supported by phylogenetic analysis (Fig. 2a). All sequences clustered inside Thaumarchaeota Marine Group 1.1b (also called Nitrososphaera cluster) (Fig. 2a). OTU 7 was the most abundant thaumarchaeal OTU, representing $80 \%$ of the recovered archaeal communities. Although this highly abundant OTU was common to all samples, and 99\% of the ridge communities were comprised of OTU 7, OTU 7 only constituted $38 \%$ of moraine communities (Table $\mathrm{S} 1)$. The remaining $62 \%$ were comprised of OTUs $1-5$, and $8(0.01-17 \%$ of all sequences $)$, which were found almost exclusively in moraines. The second most abundant OTU (OTU 1) represented 17\% of the estimated archaeal community and was closely related to N. gargensis (GU797786, 93\% maximum identity) (Hatzenpichler et al., 2008) (Fig. 2a).

\section{Euryarchaeota}

Euryarchaeota accounted for $0.005-0.01 \%$ of all archaeal sequences and included three OTUs (OTU 16-18) recovered from inland moraines near the valley floor. OTU 16 contained three sequences found only in Marshall Valley moraine 1 (Table S1), while OTU 17, represented by a singleton, and OTU 18, represented by three sequences, were only present in soil from Garwood Valley moraine 2 (Table S1). Phylogenetic analysis confirmed the placement of these OTUs within the Euryarchaeota (Fig. 2b). 


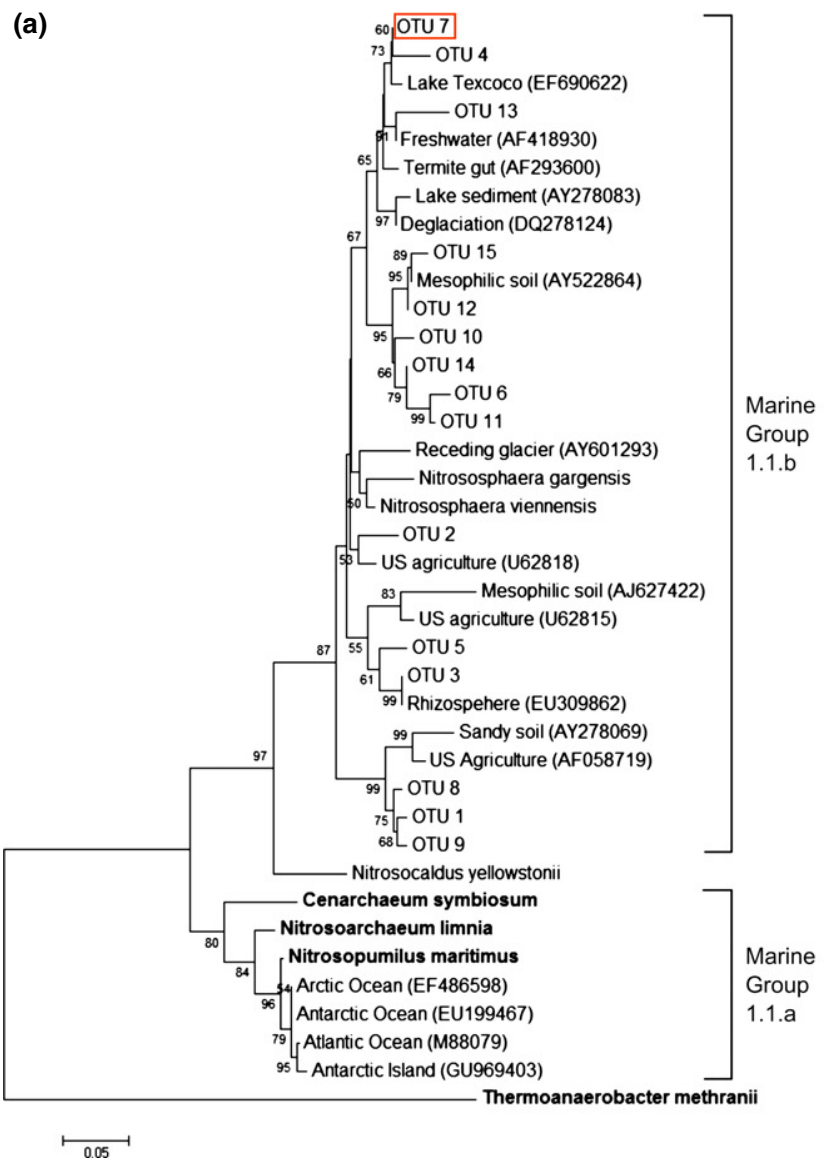

(b)

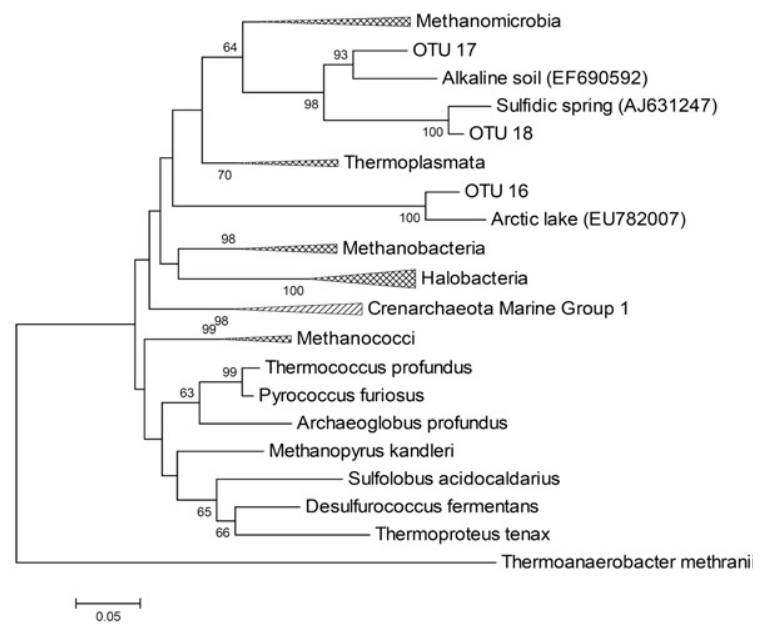

Fig. 2. Neighbor-joining tree of thaumarchaeal (a) and euryarchaeal (b) OTUs retrieved from Dry Valley soil. Reference sequences of Marine Group 1 Thaumarchaeota and sequences of isolates representing the main phylogenetic lineages of Euryarchaeota were retrieved from GenBank. Bootstrap values are calculated from 1000 replicates and are shown next to the branches. The scale bar shown represents a 5\% difference in nucleotide composition.

\section{Environmental drivers of archaeal diversity}

Multiple regression and BEST analyses were used to investigate the influence of biogeochemical soil properties (i.e., aspect, elevation, slope, soil moisture content, soil $\mathrm{pH}$, soil electrical conductivity, total organic carbon, and total nitrogen) on archaeal community structure. A significant correlation between archaeal diversity and water content was observed (Table 3, $P<0.01$ ), but BEST analysis did not detect significant correlations between archaeal community structure and environmental parameters (data not shown).

\section{Discussion}

\section{Distribution and diversity of Archaea}

We used t-RFLP fingerprinting and 454 pyrosequencing to characterize archaeal richness in multiple Dry Valley areas located in the subxerous, coastal climate zone, in the McMurdo Dry Valleys (Campbell \& Claridge, 1987).

In contrast to limited success by earlier attempts (Pointing et al., 2009; Yergeau et al., 2009; Ayton et al., 2010), we detected Archaea in all of the Antarctic soils sampled in this study. Additionally, the extensive t-RFLP analysis in this study extended the known range from coastal areas (Ayton et al., 2010) to a variety of inland landscapes such as meltwater stream deltas, coastal, and terminal moraines, lake edges, hill slopes, ridges, and polygons, including soils exceeding electrical conductivity of $5000 \mu \mathrm{sm}^{-1}$ and $\mathrm{pH}$ greater than 9.5 (Table 1). These highly alkaline and saline soils were previously thought not to be colonized by Archaea (Ayton et al., 2010).

Following t-RFLP analysis, four archaeal communities (Miers Valley ridge, Miers Marshall Valley ridge, Marshall Valley moraine 1, and Garwood Valley moraine 2) were analyzed with greater scrutiny by 454 pyrosequencing of 
Table 3. Multiple regression of environmental parameters and archaeal diversity

\begin{tabular}{llllll}
\hline Residuals & Min & 1Q & Median & 3Q & Max \\
\hline & -15.5143 & -8.0158 & -0.2628 & 6.9429 & 15.9906 \\
\hline
\end{tabular}

\begin{tabular}{lrrrl} 
Coefficients & \multicolumn{1}{c}{ Estimate } & Std error & \multicolumn{1}{c}{$t$-value } & $\operatorname{Pr}(>t)$ \\
\hline (Intercept) & 8.44892 & 6.96204 & 1.214 & 0.23505 \\
Elevation & -0.20180 & 0.23442 & -0.861 & 0.39664 \\
Slope & 0.34755 & 0.24314 & 1.429 & 0.16395 \\
Aspect & 0.06231 & 0.17446 & 0.357 & 0.72365 \\
Water & 0.49287 & 0.17452 & 2.824 & $0.00864 * *$ \\
pH & 0.05825 & 0.18036 & 0.323 & 0.74911 \\
Conductivity & -0.17474 & 0.18742 & -0.932 & 0.35913 \\
ATP & -0.04114 & 0.19574 & -0.210 & 0.83504 \\
\hline
\end{tabular}

Data were rank-transformed prior to analysis. Significance codes are as follows: $P<0.001(* *)$.

16S rRNA gene PCR amplicons. The low number of archaeal phylotypes from our study (mean of six OTUs per sample) is comparable to low diversity estimates reported for soils of the Ross Sea region (Ayton et al., 2010), McKelvey Dry Valley (Chan et al., 2013) and similar environments such as the Canadian High Arctic (Steven et al., 2008).

Small discrepancies between 454 pyrosequencing and t-RFLP diversity estimates (Table 2) may be due to overestimation of the actual community richness by t-RFLP analysis due to bacterial contamination (Dunbar et al., 2001). This is supported by the relative high proportion of bacterial sequences that were identified through pyrosequencing (Table 2).

\section{Thaumarchaeota marine group 1.1b}

More than $99 \%$ of sequences retrieved from the Dry Valley soils belonged to the newly described phylum Thaumarchaeota (Brochier-Armanet et al., 2008; Spang et al., 2010). The most abundant thaumarchaeal OTU (OTU 7) exhibited a close phylogenetic relationship with other Marine Group 1.1b Thaumarchaeota from moderate environments (Friedrich et al., 2001; Stein et al., 2002; Ochsenreiter et al., 2003; Nicol et al., 2006; ValenzuelaEncinas et al., 2008) (Fig. 2a). Thaumarchaeal species belonging to group $1.1 \mathrm{~b}$ are highly abundant and ubiquitous in terrestrial environments, where they can make up to $5 \%$ of prokaryotic $16 \mathrm{~S}$ rRNA genes (Ochsenreiter et al., 2003; Bates et al., 2011; Pester et al., 2012; Stahl \& de la Torre, 2012). Recently, members of this lineage have also been reported for coastal soils of the Ross Sea region: Scott Base, Marble Point, Granite Harbour, and Victoria Valley (Ayton et al., 2010) as well as in Antarctic cryoconite holes (Cameron et al., 2012). Pesaro et al. (2003) reported a higher resistance to freeze-thaw cycles for members of group 1.1b than for members of group 1.1a (Nitrosopumilus cluster), which may explain their ability to successfully colonize Antarctic soils, where daily temperature fluctuations greater than $20{ }^{\circ} \mathrm{C}$ can cause multiple freeze-thaw cycles within a single day (Aislabie et al., 2006).

Thaumarchaeota are key players within the global nitrogen cycle due to their involvement in nitrification (Venter et al., 2004; Koenneke et al., 2005; Hatzenpichler et al., 2008). During the first step of nitrification, autotrophic Thaumarchaeota oxidize ammonia to nitrite $\left(\mathrm{NH}_{3} \rightarrow \mathrm{NH}_{2} \mathrm{OH} \rightarrow \mathrm{NO}_{2}\right)$, mediated by ammonia monooxygenase $(a m o A)$. In one study, the abundance of amo $A$ indicated that ammonia-oxidizing Thaumarchaeota outnumber their bacterial counterparts in soil, particularly at depth (Leininger et al., 2006). It has been shown that Thaumarchaeota affiliated with group $1.1 \mathrm{~b}$ contribute to oxidation of ammonia across a wide range of habitats (Treusch et al., 2005; Leininger et al., 2006; Hatzenpichler et al., 2008). Antarctic soils are characterized by high levels of salinity (Bockheim, 1997; Barrett et al., 2007), with ammonia comprising a small fraction of total soil nitrogen in continental Antarctica (Barrett et al., 2009; Magalhaes et al., 2012). Interestingly, N. gargensis has been shown to be inhibited by total ammonium concentrations in the lower mM-range (Hatzenpichler et al., 2008) giving physiological support for a preference of low substrate concentrations (Leininger et al., 2006). Based on our findings, we propose that this Antarctic soil Thaumarchaeota may also be an ammonia oxidizer as it clustered within the Thaumarchaeota, which included the 16S rRNA gene from a Thaumarchaeota fosmid 54d9 (AJ627422, Fig. 2a), containing amoA (Treusch et al., 2005). This is supported by the presence of ammonia-oxidizing Archaea in Antarctic soils from coastal areas, which were shown to be well adapted to cold temperatures (Jung et al., 2011; Han et al., 2013) as well as the recent discovery of amoA in soils and lithic environments from the McKelvey Dry Valley (Chan et al., 2013). However, to strengthen the phylogenetic observations described in this study, future investigations are needed to identify the role of Thaumarchaeota in Antarctic soils and their potential involvement in ammonia oxidation.

\section{Euryarchaeota}

Putative Euryarchaeota were also present in soils from inland moraines located near the valley floor, although apparently at very low abundances $(<0.02 \%)$. Most of the euryarchaeal OTUs detected in Dry Valley soils were very loosely related to Methanosarcinales and environmental sequences retrieved from cold sulfidic springs (Rudolph et al., 2004) and the former Lake Texcoco, 
Mexico (Valenzuela-Encinas et al., 2008). Although species belonging to the Methanosarcinales are present in subglacial Antarctic environments (Stibal et al., 2012), Antarctic lake sediments (Purdy et al., 2003; Karr et al., 2006), and surface waters (Brambilla et al., 2001; Taton et al., 2003), Methanosarcinales have not previously been detected in Dry Valley soils, and further investigations are required to confidentially place these archaeal phylotypes within the Euryarchaeota and assign them to specific lineages.

\section{Physicochemical drivers of archaeal diversity}

Species richness at local sites (alpha-diversity) is most likely influenced by soil water content (Table 3), although BEST analysis failed to detect correlations between differences in archaeal community structure and differences in environmental parameters (data not shown). Water availability has been shown to crucially influence the composition of soil communities (Barrett et al., 2004; Aislabie et al., 2006) and is considered the primary limiting resource for microbial life in terrestrial regions of Antarctica (Kennedy, 1993; Gregorich et al., 2006). Water availability is locally high in elevated areas due to condensation, snowfalls, presence of snow patches, and subsequent snowmelt (Schroeter et al., 2010; Green et al., 2011; Eveland et al., 2013; Van Horn et al., 2013). The importance of snowmelt as a source of moisture has been reported for the crustose lichen Buellia frigid in southern continental Antarctica (Kappen et al., 1998), which can only be found on slopes higher than $600 \mathrm{~m}$ but not in the valley floor (Kappen et al., 1981; Sancho et al., 2007).

Failure to detect environmental influences using BEST analysis may be explained by high levels of variation in physical and chemical soil properties within a single sample. The severity of the Dry Valley environment and extreme desiccation has led to highly heterogeneous soils creating protected environments for microbial colonization (Cockell \& Stokes, 2004). The most substantial of these are lithic environments, where well-developed microbial communities have colonized cracks in rocks (endolithic communities), the undersides of translucent rocks (hypolithic communities), and surface rock 'flakes' produced by laminar weathering (chasmolithic communities). These microniches potentially provide physical stability, desiccation buffering, increased water availability, and protection from UV fluxes for residing microorgnisms (Cary et al., 2010). For example, hypolithic communities were shown to represent local 'hotspots' of microbial diversity (Smith et al., 2000) and productivity (Pointing \& Belnap, 2012) compared to soils. The mean productivity of these communities is equivalent to those of lichens and bryophytes (Cockell \& Stokes, 2004), possibly exceeding productivity levels in open Dry Valley soils.
Moreover, large regional differences in edaphic soil characteristics such as $\mathrm{pH}$, soil organic carbon, and conductivity are likely to generate differences in bacterial communities in Dry Valley soils (Van Horn et al., 2013).

\section{Summary}

For the first time, Archaea were successfully detected and characterized in all inland and coastal mineral soils in the three southern most McMurdo Dry Valleys. This systematic, landscape-scale study revealed an extensive distribution of archaeal communities in Antarctic mineral soils. Archaeal communities are not limited to coastal margins as previously thought and are instead present in inland glacial push moraines, high elevation ridge areas, slopes, and inland plains. T-RFLP fingerprinting analysis and 454 high-throughput sequencing revealed low archaeal richness in all samples analyzed. However, archaeal richness was higher in some soils, and this higher richness was significantly correlated with soil water content revealed by multiple regressions. Dry Valley soil archaeal communities examined were dominated by a potential ammonia oxidizer affiliated with the globally abundant Thaumarchaeota Marine Group 1.1b, and a number of potential Euryarchaeota were found exclusively associated with inland glacial push moraine. Future studies should focus on detection and functional characterization of ammoniaoxidizing Thaumarchaeota and Euryarchaeota to understand their role and potential involvement in the nitrogen and carbon cycles in Antarctic soils.

\section{Acknowledgements}

nzTABS was supported by funding from the Foundation for Research, Science and Technology and the International Centre for Terrestrial Antarctic Research. We acknowledge Antarctica New Zealand for logistics and their overriding support for the project. We especially thank Eric Bottos and Sarah Kelly (Waikato University) for assistance with DNA extraction and sample preparation for 454 pyrosequencing that was carried out at the Waikato DNA Sequencing Facility, Hamilton, New Zealand. We thank Steve Pointing for help with the manuscript. This research was also partially supported by a National Science Foundation grant to SCC and JEB (ANT-0229836). The New Zealand Marsden Fund provided financial support for CWH, IRM, and SCC (UOW0802) and CKL (UOW1003).

\section{References}

Abdo Z, Schuette UME, Bent SJ, Williams CJ, Forney LJ \& Joyce P (2006) Statistical methods for characterizing 
diversity of microbial communities by analysis of terminal restriction fragment length polymorphisms of $16 \mathrm{~S}$ rRNA genes. Environ Microbiol 8: 929-938.

Adams BJ, Bardgett RD, Ayres E et al. (2006) Diversity and distribution of Victoria Land biota. Soil Biol Biochem 38: 3003-3018.

Aislabie JM, Chhour KL, Saul DJ, Miyauchi S, Ayton J, Paetzold RF \& Balks MR (2006) Dominant bacteria in soils of Marble Point and Wright Valley, Victoria land, Antarctica. Soil Biol Biochem 38: 3041-3056.

Ayton J, Aislabie J, Barker GM, Saul D \& Turner S (2010) Crenarchaeota affiliated with group $1.1 \mathrm{~b}$ are prevalent in coastal mineral soils of the Ross Sea region of Antarctica. Environ Microbiol 12: 689-703.

Barrett JE, Virginia RA, Wall DH, Parsons AN, Powers LE \& Burkins MB (2004) Variation in biogeochemistry and soil biodiversity across spatial scales in a Polar Desert Ecosystem. Ecology 85: 3105-3118.

Barrett J, Virginia R, Wall D, Cary SC, Adams B \& Hacker A (2006) Co-variation in soil biodiversity and biogeochemistry in Northern and Southern Victoria Land, Antarctica. Antarct Sci 18: 535-548.

Barrett JE, Virginia RA, Lyons WB et al. (2007) Biogeochemical stoichiometry of Antarctic Dry Valley ecosystems. J Geophys Res Biogeosci 112: 12.

Barrett JE, Gooseff MN \& Takacs-Vesbach C (2009) Spatial variation in soil active-layer geochemistry across hydrologic margins in polar desert ecosystems. Hydrol Earth Syst Sci 13: 2349-2358.

Bates ST, Berg-Lyons D, Caporaso JG, Walters WA, Knight R \& Fierer N (2011) Examining the global distribution of dominant archaeal populations in soil. ISME J 5: 908-917.

Bintrim SB, Donohue TJ, Handelsman J, Roberts GP \& Goodman RM (1997) Molecular phylogeny of Archaea from soil. P Natl Acad Sci USA 94: 277-282.

Bockheim JG (1997) Properties and classification of cold desert soils from Antarctica. Soil Sci Soc Am J 61: 224-231.

Bockheim JG (2002) Landform and soil development in the McMurdo Dry Valleys, Antarctica: a regional synthesis. Arct Antarct Alp Res 34: 308-317.

Brambilla E, Hippe H, Hagelstein A, Tindall BJ \& Stackebrandt E (2001) 16S rDNA diversity of cultured and uncultured prokaryotes of a mat sample from Lake Fryxell, McMurdo Dry Valleys, Antarctica. Extremophiles 5: 23-33.

Brochier-Armanet C, Boussau B, Gribaldo S \& Forterre P (2008) Mesophilic Crenarchaeota: proposal for a third archaeal phylum, the Thaumarchaeota. Nat Rev Microbiol 6: 245-252.

Brook EJ, Kurz MD, Ackert RP, Raisbeck G \& Yiou F (1995) Cosmogenic nuclide exposure ages and glacial history of Late Quaternary Ross Sea Drift in McMurdo Sound, Antarctica. Earth Planet Sci Lett 131: 41-56.

Buckley DH, Graber JR \& Schmidt TM (1998) Phylogenetic analysis of nonthermophilic members of the kingdom Crenarchaeota and their diversity and abundance in soils. Appl Environ Microbiol 64: 4333-4339.
Cameron KA, Hodson AJ \& Osborn AM (2012) Structure and diversity of bacterial, eukaryotic and archaeal communities in glacial cryoconite holes from the Arctic and the Antarctic. FEMS Microbiol Ecol 82: 254-267.

Campbell IB \& Claridge GGC (1987) Antarctica: Soils, Weathering Processes and Environment. Elsevier Science Pub. Co., Inc., New York.

Cary SC, McDonald IR, Barrett JE \& Cowan DA (2010) On the rocks: the microbiology of Antarctic Dry Valley soils. Nat Rev Microbiol 8: 129-138.

Chan YK, Van Nostrand JD, Zhou JZ, Pointing SB \& Farrell RL (2013) Functional ecology of an Antarctic Dry Valley. $P$ Natl Acad Sci USA 110: 8990-8995.

Chao A (1987) Estimating the population size for capture-recapture data with unequal catchability. Biometrics 43: 783-791.

Cockell CS \& Stokes MD (2004) Ecology - widespread colonization by polar hypoliths. Nature 431: 414 .

Convey P (1996) The influence of environmental characteristics on life history attributes of Antarctic terrestrial biota. Biol Rev Camb Philos Soc 71: 191-225.

Denton GH, Bockheim JG, Wilson SC \& Stuiver M (2004) Late Wisconsin and early Holocene glacial history, inner Ross Embayment, Antarctica. Quatern Res 31: 151-182.

Doran PT, Priscu JC, Lyons WB et al. (2002) Antarctic climate cooling and terrestrial ecosystem response. Nature 415: 517-520.

Dunbar J, Ticknor LO \& Kuske CR (2001) Phylogenetic specificity and reproducibility and new method for analysis of terminal restriction fragment profiles of 16S rRNA genes from bacterial communities. Appl Environ Microbiol 67: 190-197.

Edmeades DC, Wheeler DM \& Clinton OE (1985) The chemical composition and ionic strength of soil solutions from New Zealand topsoils. Aust J Soil Res 23: 151-165.

Elberling B, Gregorich EG, Hopkins DW, Sparrow AD, Novis P \& Greenfield LG (2006) Distribution and dynamics of soil organic matter in an Antarctic Dry Valley. Soil Biol Biochem 38: 3095-3106.

Eveland JW, Gooseff MN, Lampkin DJ, Barrett JE \& Takacs-Vesbach C (2013) Seasonal controls on snow distribution and aerial ablation at the snow-patch and landscape scales, McMurdo Dry Valleys, Antarctica. The Cryosphere 7: 917-931.

Freckman DW \& Virginia RA (1997) Low-diversity Antarctic soil nematode communities: distribution and response to disturbance. Ecology 78: 363-369.

Friedrich MW, Schmitt-Wagner D, Lueders T \& Brune A (2001) Axial differences in community structure of Crenarchaeota and Euryarchaeota in the highly compartmentalized gut of the soil-feeding termite Cubitermes orthognathus. Appl Environ Microbiol 67: 4880-4890.

Gooseff MN, Barrett JE \& Levy JS (2012) Shallow groundwater systems in a polar desert, McMurdo Dry Valleys, Antarctica. Hydrogeol J 21: 171-183. 
Green TGA, Sancho LG, Pintado A \& Schroeter B (2011) Functional and spatial pressures on terrestrial vegetation in Antarctica forced by global warming. Polar Biol 34: 1643-1656.

Gregorich EG, Hopkins DW, Elberling B, Sparrow AD, Novis P, Greenfield LG \& Rochette P (2006) Emission of CO2, $\mathrm{CH} 4$ and $\mathrm{N} 2 \mathrm{O}$ from lakeshore soils in an Antarctic Dry Valley. Soil Biol Biochem 38: 3120-3129.

Han J, Jung J, Park M, Hyun S \& Park W (2013) Short-term effect of elevated temperature on the abundance and diversity of bacterial and archaeal amoA genes in Antarctic Soils. J Microbiol Biotechnol 23: 1187-1196.

Hatzenpichler R, Lebedeva EV, Spieck E, Stoecker K, Richter A, Daims H \& Wagner M (2008) A moderately thermophilic ammonia-oxidizing crenarchaeote from a hot spring. P Natl Acad Sci USA 105: 2134-2139.

Hogg ID, Cary SC, Convey P et al. (2006) Biotic interactions in Antarctic terrestrial ecosystems: are they a factor? Soil Biol Biochem 38: 3035-3040.

Jung J, Yeom J, Kim J et al. (2011) Change in gene abundance in the nitrogen biogeochemical cycle with temperature and nitrogen addition in Antarctic soils. Res Microbiol 162: 1018-1026.

Jurgens G, Lindstrom K \& Saano A (1997) Novel group within the kingdom Crenarchaeota from boreal forest soil. Appl Environ Microbiol 63: 803-805.

Kappen L, Friedmann EI \& Garty J (1981) Ecophysiology of lichens in the Dry Valleys of Southern Victoria Land, Antarctica. I. Microclimate of the cryptoendolithic lichen habitat. Flora 171: 216-235.

Kappen L, Schroeter B, Green TGA \& Seppelt RD (1998) Microclimatic conditions, meltwater moistening, and the distributional pattern of Buellia frigida on rock in a southern continental Antarctic habitat. Polar Biol 19: 101-106.

Karr EA, Ng JM, Belchik SM, Sattley WM, Madigan MT \& Achenbach LA (2006) Biodiversity of methanogenic and other Archaea in the permanently frozen Lake Fryxell, Antarctica. Appl Environ Microbiol 72: 1663-1666.

Kennedy AD (1993) Water as a limiting factor in the Antarctic terrestrial environment- A biogeographical synthesis. Arct Alp Res 25: 308-315.

Koenneke M, Bernhard AE, De la Torre JR, Walker CB, Waterbury JB \& Stahl DA (2005) Isolation of an autotrophic ammonia-oxidizing marine archaeon. Nature 437: 543-546.

Lee CK, Barbier BA, Bottos EM, McDonald IR \& Cary SC (2012) The inter-valley soil comparative survey: the ecology of Dry Valley edaphic microbial communities. ISME J 6: 1046-1057.

Leininger S, Urich T, Schloter M et al. (2006) Archaea predominate among ammonia-oxidizing prokaryotes in soils. Nature 442: 806-809.

Levy J (2012) How big are the McMurdo Dry Valleys? Estimating ice-free area using Landsat image data. Antarct Sci 1: 1-2.
Magalhaes C, Stevens MI, Cary SC et al. (2012) At limits of life: multidisciplinary insights reveal environmental constraints on biotic diversity in continental Antarctica. PLoS ONE 7: e44578.

Nicol GW \& Schleper C (2006) Ammonia-oxidising Crenarchaeota: important players in the nitrogen cycle? Trends Microbiol 14: 207-212.

Nicol GW, Tscherko D, Embley TM \& Prosser JI (2005) Primary succession of soil Crenarchaeota across a receding glacier foreland. Environ Microbiol 7: 337-347.

Nicol GW, Tscherko D, Chang L, Hammesfahr U \& Prosser JI (2006) Crenarchaeal community assembly and microdiversity in developing soils at two sites associated with deglaciation. Environ Microbiol 8: 1382-1393.

Niederberger TD, McDonald IR, Hacker AL, Soo RM, Barrett JE, Wall DH \& Cary SC (2008) Microbial community composition in soils of Northern Victoria Land, Antarctica. Environ Microbiol 10: 1713-1724.

Ochsenreiter T, Selezi D, Quaiser A, Bonch-Osmolovskaya L \& Schleper C (2003) Diversity and abundance of Crenarchaeota in terrestrial habitats studied by 16S RNA surveys and real time PCR. Environ Microbiol 5: 787-797.

Pesaro M, Widmer F, Nicollier G \& Zeyer J (2003) Effects of freeze-thaw stress during soil storage on microbial communities and methidathion degradation. Soil Biol Biochem 35: 1049-1061.

Pester M, Rattei T, Flechl S et al. (2012) amoA-based consensus phylogeny of ammonia-oxidizing archaea and deep sequencing of amoA genes from soils of four different geographic regions. Environ Microbiol 14: 525-539.

Pewe TL (1958) Quaternary glacial geology of the McMurdo Sound region, Antarctica- a progress report. IGY Glaciological Rept 1: 1-4.

Pewe TL (1960) Multiple glaciation in the McMurdo Sound region, Antarctica: A progress report. J Geol 68: 498-514.

Poage MA, Barrettt JE, Virginia RA \& Wall DH (2008) The influence of soil geochemistry on nematode distribution, McMurdo Dry Valleys, Antarctica. Arct Antarct Alp Res 40: 119-128.

Pointing SB \& Belnap J (2012) Microbial colonization and controls in dryland systems. Nat Rev Microbiol 10: 551-552.

Pointing SB, Chan Y, Lacap DC, Lau MCY, Jurgens JA \& Farrell RL (2009) Highly specialized microbial diversity in hyper-arid polar desert. P Natl Acad Sci USA 107: 1254.

Purdy KJ, Nedwell DB \& Embley TM (2003) Analysis of the sulfate-reducing bacterial and methanogenic archaeal populations in contrasting Antarctic sediments. Appl Environ Microbiol 69: 3181-3191.

Quince C, Lanzen A, Davenport RJ \& Turnbaugh PJ (2011) Removing noise from pyrosequenced amplicons. BMC Bioinformatics 12: 38 .

Rudolph C, Moissl C, Henneberger R \& Huber R (2004) Ecology and microbial structures of archaeal/bacterial string-of-pearls communities and archaeal relatives thriving in cold sulfidic springs. FEMS Microbiol Ecol 50: $1-11$. 
Rueckert A \& Morgan HW (2007) Removal of contaminating DNA from polymerase chain reaction using ethidium monoazide. J Microbiol Methods 68: 596-600.

Saitou N \& Nei M (1987) The neighbor-joining method - a new method for reconstructing phylogenetic trees. Mol Biol Evol 4: 406-425.

Sancho LG, Green TGA \& Pintadoa A (2007) Slowest to fastest: Extreme range in lichen growth rates supports their use as an indicator of climate change in Antarctica. Flora 202: 667-673.

Schloss PD, Westcott SL, Ryabin T et al. (2009) Introducing MOTHUR: open-source, platform-independent, community-supported software for describing and comparing microbial communities. Appl Environ Microbiol 75: 7537-7541.

Schroeter B, Green TGA, Pannewitz S, Schlensog M \& Sancho LG (2010) Fourteen degrees of latitude and a continent apart: comparison of lichen activity over two years at continental and maritime Antarctic sites. Antarct Sci 22: 681-690.

Smith MC, Bowman JP, Scott FJ \& Line MA (2000) Sublithic bacteria associated with Antarctic quartz stones. Antarct Sci 12: 177-184.

Smith JJ, Tow LA, Stafford W, Cary C \& Cowan DA (2006) Bacterial diversity in three different Antarctic cold desert mineral soils. Microb Ecol 51: 413-421.

Spang A, Hatzenpichler R, Brochier-Armanet C et al. (2010) Distinct gene set in two different lineages of ammonia-oxidizing Archaea supports the phylum Thaumarchaeota. Trends Microbiol 18: 331-340.

Stahl DA \& Amann R (1991) Development and Application of Nucleic Acid Probes in Bacterial Systematics. John Wiley \& Sons Ltd., Chichester, England.

Stahl DA \& De la Torre JR (2012) Physiology and diversity of ammonia-oxidizing Archaea. Annu Rev Microbiol 66: 83-101.

Stein LY, Jones G, Alexander B, Elmund K, Wright-Jones C \& Nealson KH (2002) Intriguing microbial diversity associated with metal-rich particles from a freshwater reservoir. FEMS Microbiol Ecol 42: 431-440.

Steven B, Pollard WH, Greer CW \& Whyte LG (2008) Microbial diversity and activity through a permafrost/ ground ice core profile from the Canadian high Arctic. Environ Microbiol 10: 3388-3403.

Stibal M, Wadham JL, Lis GP et al. (2012) Methanogenic potential of Arctic and Antarctic subglacial environments with contrasting organic carbon sources. Glob Change Biol 18: 3332-3345.

Stonehouse B (2002) Encyclopedia of Antarctica and the Southern Oceans. John Wiley \& Sons, Chichester, England.

Sun Y, Cai Y, Liu L, Yu F, Farrell ML, McKendree W \& Farmerie W (2009) ESPRIT: estimating species richness using large collections of $16 \mathrm{~S}$ rRNA pyrosequences. Nucleic Acids Res 37: e76.

Tamura K, Dudley J, Nei M \& Kumar S (2007) MEGA4: Molecular Evolutionary Genetics Analysis (MEGA) software version 4.0. Mol Biol Evol 24: 1596-1599.
Tamura K, Nei M \& Kumar S (2004) Prospects for inferring very large phylogenies by using the neighbor-joining method. P Natl Acad Sci USA 101: 11030-11035.

Taton A, Grubisic S, Brambilla E, De Wit R \& Wilmotte A (2003) Cyanobacterial diversity in natural and artificial microbial mats of Lake Fryxell (McMurdo Dry Valleys, Antarctica): A morphological and molecular approach. Appl Environ Microbiol 69: 5157-5169.

Thompson JD, Higgins DG \& Gibson TJ (1994) CLUSTAL-WImproving the sensitivity of progressive multiple sequence alignment through sequence weighting, position-specific gap penalties and weight matrix choice. Nucleic Acids Res 22: 4673-4680.

Treusch AH, Leininger S, Kletzin A, Schuster SC, Klenk HP \& Schleper C (2005) Novel genes for nitrite reductase and amo-related proteins indicate a role of uncultivated mesophilic crenarchaeota in nitrogen cycling. Environ Microbiol 7: 1985-1995.

Valenzuela-Encinas C, Neria-Gonzalez I, Alcantara-Hernandez RJ et al. (2008) Phylogenetic analysis of the archaeal community in an alkaline-saline soil of the former lake Texcoco (Mexico). Extremophiles 12: 247-254.

Van Horn DJ, Van Horn ML, Barrett JE et al. (2013) Factors controlling soil microbial biomass and bacterial diversity and community composition in a cold desert ecosystem: role of geographic scale. PLoS ONE 8: e66103.

Venter JC, Remington K, Heidelberg JF et al. (2004) Environmental genome shotgun sequencing of the Sargasso Sea. Science 304: 66-74.

Vishniac HS (1993) Antarctic Microbiology. Wiley-Liss, New York, pp. 297-341.

Wang Q, Garrity GM, Tiedje JM \& Cole JR (2007) Naive Bayesian classifier for rapid assignment of rRNA sequences into new bacterial taxonomy. Appl Environ Microbiol 73: 5261-5267.

Wynn-Williams DD (1990) Ecological aspects of Antarctic microbiology. Adv Microb Ecol 11: 71-146.

Yergeau E, Schoondermark-Stolk SA, Brodie EL et al. (2009) Environmental microarray analyses of Antarctic soil microbial communities. ISME J 3: 340-351.

Zeglin LH, Dahm CN, Barrett JE, Gooseff MN, Fitpatrick SK \& Takacs-Vesbach CD (2011) Bacterial community structure along moisture gradients in the parafluvial sediments of two ephemeral desert streams. Microb Ecol 61: 543-556.

\section{Supporting Information}

Additional Supporting Information may be found in the online version of this article:

Table S1. OTU abundances of archaeal sequences recovered from Antarctic Dry Valley soil.

Fig. S1. Rarefaction curves for pyrosequencing effort. OTUs were defined by mean neighbor $\mathrm{d}=0.03$. 